\title{
Preface to the
}

\section{Enlarged Edition}

In this book I develop an economic or rational choice approach to the family. The title does not refer to economic aspects of the family, however, because most noneconomists and many economists would interpret the qualifier "economic" to indicate that the discussion is confined to the material aspects of family life, to incomes and spending patterns. My intent is more ambitious: to analyze marriage, births, divorce, division of labor in households, prestige, and other nonmaterial behavior with the tools and framework developed for material behavior. That is to say, this book contains an economic approach to the family, not in the sense of an emphasis on the material aspects of family life, but in the sense of a choice-theoretic framework for analyzing many aspects of family life.

The rational choice approach has been refined during the past two hundred years. It now assumes that individuals maximize their utility from basic preferences that do not change rapidly over time, and that the behavior of different individuals is coordinated by explicit and implicit markets. I argued in an earlier publication that the economic approach is not restricted to material goods and wants or to markets with monetary transactions, and conceptually does not distinguish be- 
tween major and minor decisions or between "emotional" and other decisions.

This volume uses the assumptions of maximizing behavior, stable preferences, and equilibrium in implicit or explicit markets to provide a systematic analysis of the family. I build on my research during the past two decades to analyze the allocation of time to children and to market work, marriage and divorce in polygynous as well as monogamous societies, altruism in addition to selfishness in families, intergenerational mobility, and many other aspects of the family. Although not all are considered, the systematic, unified treatment of the important aspects perhaps justifies the old-fashioned title "treatise."

My book is not written for a lay audience, but much of the material should be understandable to noneconomists familiar with basic economic principles. Chapters 5, 10, and 11, including the supplement to Chapter 11, are the least technical, and appreciable portions of other chapters should also be accessible to persons having only a limited acquaintance with economic analysis. I hope they will not be put off by the terminology and techniques, for their participation is required to achieve a full development and evaluation of the rational choice approach to the family. I say this because many economists are hostile to this application of the approach, whereas increasing numbers of sociologists, anthropologists, lawyers, biologists, psychologists, and historians are using a rational choice approach or related methods to analyze the family. My "treatise" is intended for an interdisciplinary audience-for skeptics as well as for advocates.

I have immensely enjoyed writing this book because of the importance of the subject matter and the intellectual challenges provided by many aspects of family organization and behavior. I would be less than truthful if I did not express my belief that substantial progress has been made in meeting and resolving these challenges. At the same time, I am aware of and disturbed by serious omissions and incomplete analyses; I delayed publication of the earlier edition several times to fill in gaps and improve certain of the discussions. I finally decided to delay no longer and to publish the book because others, noneconomists as well as economists, can better carry on these efforts to understand the major institution throughout history in essentially all human societies.

The remarkable changes in family behavior and structure during the past several decades in countries throughout the world contributed greatly to the attention paid to the first edition of the Treatise, despite 
its technical nature. The book was widely reviewed by economists, sociologists, demographers, and also by a few biologists and psychologists, and has been translated into several languages. Since I have continued to work on the family, I was happy to agree to a proposal by the publisher that I prepare an enlarged edition.

\section{Acknowledgments}

I incurred numerous debts in the preparation of this book. Let me begin by thanking colleagues and students at the University of Chicago for creating the stimulating atmosphere I have experienced here. Economics is taken seriously at Chicago, and ideas are considered and analyzed in a frank and searching manner without intellectual inertia or excessive respect for authority or for boundaries between disciplines. I have especially benefited from the following students who wrote dissertations on the family, or relevant to the family, during their participation in our Workshop on Applications of Economics: James Adams, Wallace Blackhurst, Michael Brien, Dennis De Tray, Alan Freiden, Miguel Gomez, Daniel Gros, Amyra Grossbard, Nadeem Haque, Boyan Jovanovic, Michael Keeley, Lawrence Kenny, Ayal Kimhi, Edy Kogut, Sui Fai Leung, Daniel Levy, Luis Locay, Thomas MaCurdy, Indra Makhija, Gabriel Martinez, Haim Ofek, Elizabeth Peters, Seth Sanders, James Smith, Jeffrey Smith, Robert Tamura, Nigel Tomes, Grace Tsiang, Jenny Bourne Wahl, Walter Wessels, Louis Wilde, Richard Wong, and Martin Zelder.

I have prepared a new Introduction for this enlarged edition, and I am including slightly modified versions of four articles published subsequent to the 1981 edition. One article was written jointly with Robert J. Barro, another with Kevin M. Murphy, and a third with Nigel Tomes.

I am indebted to Robert Michael, Richard Posner, Sherwin Rosen, T. W. Schultz, and George Stigler for helpful and detailed suggestions on all the chapters. Valuable comments also came from Stuart Altmann, Michael Aronson, Edward Banfield, Reuven Brenner, Arthur Diamond, Ted Frech, David Friedman, Milton Friedman, Victor Fuchs, David Galenson, Matthew Goldberg, Arthur Goldberger, Zvi Griliches, Reuben Gronau, Amyra Grossbard, Sanford Grossman, James Heckman, David Hirshleifer, Jack Hirshleifer, Arcadius Kahan, Lawrence Kenny, Elisabeth Landes, Richard Layard, H. Gregg 


\section{xii ] Preface to the Enlarged Edition}

Lewis, Robert Lucas, Jacob Mincer, John Muellbauer, Kevin M. Murphy, Sam Peltzman, Edward Prescott, Sam Preston, Margaret Reid, Paul Romer, Nasser Saidi, José Scheinkman, James Smith, Stephen Stigler, Larry Summers, Robert Tamura, Nigel Tomes, Yoram Weiss, Robert Willis, Edward Wilson, and Kenneth Wolpin. Vivian Wheeler provided excellent editorial assistance in both editions, and Dan Greenway skillfully drew virtually all of the figures. Michael Aronson was again a most cooperative and encouraging editor.

My research on the family has been generously supported by the University of Chicago's Center for the Study of Economy and the State, the Lilly Foundation, the National Institute of Child Health and Human Development (Grant \#SSP 1 R37 HD22054), the National Science Foundation (Grants \#SES-8012187 and \#SES-8520258), the Lynde and Harry Bradley Foundation, and the Sloan Foundation, both of which also aided our Workshops on the Family. The National Bureau of Economic Research, especially the Center for Economic Analysis of Human Behavior and Social Institutions, over a period of years provided funding, encouragement, and freedom to pursue my research in any direction that seemed promising. The views expressed here are my own and not necessarily those of the granting agencies.

Finally, let me express my deep appreciation to: Gale Mosteller, who worked on the first edition, for conscientious, thorough, and remarkably outstanding research assistance; Michael Gibbs, for valuable research aid on the supplements; David Meltzer, for truly excellent work in preparing the index and bibliography and generally in helping with the enlarged edition; Myrna Hieke, for extraordinary typing and other secretarial assistance through many not-so-legible drafts and under trying circumstances during both editions; and my wife, Guity Nashat, for numerous discussions-especially about the family in Islamic societies - as well as for the reasons given in the dedication. 


\section{National Bureau of Economic Research \\ Officers}

Eli Shapiro, chairman

Franklin A. Lindsay, vice-chairman

Martin Feldstein, president

Charles E. McLure, Jr., vice-president
Charles A. Walworth, treasurer

Sam Parker, director of finance and administration
Moses Abramovitz

George T. Conklin, Jr.

Morton Ehrlich

Solomon Fabricant

Martin Feldstein

Edward L. Ginzton

David L. Grove

Walter W. Heller

Franklin A. Lindsay

Roy E. Moor

Geoffrey H. Moore

\section{Directors at Large}

Michael H. Moskow

James J. O'Leary

Peter G. Peterson

Robert V. Roosa

Richard N. Rosett

Bert Seidman

Eli Shapiro

Stephen Stamas

Lazare Teper

Donald S. Wasserman

Marina v.N. Whitman

\section{Directors by University Appointment}

Charles H. Berry, Princeton

Otto Eckstein, Harvard

Walter D. Fisher, Northwestern

J. C. LaForce, California, Los Angeles

Paul McCracken, Michigan

Daniel McFadden, Massachusetts

Institute of Technology

Almarin Phillips, Pennsylvania
James L. Pierce, California, Berkeley

Lloyd G. Reynolds, Yale

Nathan Rosenberg, Stanford

James Simler, Minnesota

William S. Vickrey, Columbia

Dudley Wallace, Duke

Burton A. Weisbrod, Wisconsin

Arnold Zellner, Chicago

\section{Directors by Appointment of Other Organizations}

Carl F. Christ, American Economic Association

Robert C. Holland, Committee for

Economic Development

Stephan F. Kaliski, Canadian Economics Association

Albert G. Matamoros, National

Association of Business Economists

Douglass C. North, Economic History.

Association
Rudolph A. Oswald, American Federation of Labor and Congress of Industrial Organizations

Joel Popkin, American Statistical Association

G. Edward Schuh, American Agricultural Economics Association

James C. Van Horne, American Finance Association

Charles A. Walworth, American Institute of Certified Public Accountants

\section{Directors Emeriti}

Arthur F. Burns Emilio G. Collado Frank W. Fetter Thomas D. Flynn Gottfried Haberler Albert J. Hettinger, Jr.
George B. Roberts

Murray Shields

Boris Shishkin

Willard L. Thorp

Theodore O. Yntema 


\section{Relation of the Directors to the Work and Publications of the National Bureau of Economic Research}

1. The object of the National Bureau of Economic Research is to ascertain and to present to the public important economic facts and their interpretation in a scientific and impartial manner. The Board of Directors is charged with the responsibility of ensuring that the work of the National Bureau is carried on in strict conformity with this object.

2. The President of the National Bureau shall submit to the Board of Directors, or to its Executive Committee, for their formal adoption all specific proposals for research to be instituted.

3. No research report shall be published by the National Bureau until the President has sent each member of the Board a notice that a manuscript is recommended for publication and that in the President's opinion it is suitable for publication in accordance with the principles of the National Bureau. Such notification will include an abstract or summary of the manuscript's content and a response form for use by those Directors who desire a copy of the manuscript for review. Each manuscript shall contain a summary drawing attention to the nature and treatment of the problem studied, the character of the data and their utilization in the report, and the main conclusions reached.

4. For each manuscript so submitted, a special committee of the Directors (including Directors Emeriti) shall be appointed by majority agreement of the President and Vice Presidents (or by the Executive Committee in case of inability to decide on the part of the President and Vice Presidents), consisting of three Directors selected as nearly as may be one from each general division of the Board. The names of the special manuscript committee shall be stated to each Director when notice of the proposed publication is submitted to him. It shall be the duty of each member of the special manuscript committee to read the manuscript. If each member of the manuscript committee signifies his approval within thirty days of the transmittal of the manuscript, the report may be published. If at the end of that period any member of the manuscript committee withholds his approval, the President shall then notify each member of the Board, requesting approval or disapproval of publication, and thirty days additional shall be granted for this purpose. The manuscript shall then not be published unless at least a majority of the entire Board who shall have voted on the proposal within the time fixed for the receipt of votes shall have approved.

5. No manuscript may be published, though approved by each member of the special manuscript committee, until forty-five days have elapsed from the transmittal of the report in manuscript form. The interval is allowed for the receipt of any memorandum of dissent or reservation, together with a brief statement of his reasons, that any member may wish to express; and such memorandum of dissent or reservation shall be published with the manuscript if he so desires. Publication does not, however, imply that each member of the Board has read the manuscript, or that either members of the Board in general or the special committee have passed on its validity in every detail.

6. Publications of the National Bureau issued for informational purposes concerning the work of the Bureau and its staff, or issued to inform the public of activities of Bureau staff, and volumes issued as a result of various conferences involving the National Bureau shall contain a specific disclaimer noting that such publication has not passed through the normal review procedures required in this resolution. The Executive Committee of the Board is charged with review of all such publications from time to time to ensure that they do not take on the character of formal research reports of the National Bureau, requiring formal Board approval.

7. Unless otherwise determined by the Board or exempted by the terms of para graph 6, a copy of this resolution shall be printed in each National Bureau publication.

(Resolution adopted October 25, 1926, as revised through September 30, 1974) 


\section{A Treatise on the Family}


